Apidologie, 1979, 10 (2), 149-155

\title{
NUMBER OF WORKER BEES NECESSARY TO ATTEND INSTRUMENTALLY INSEMINATED QUEENS KEPT IN AN INCUBATOR
}

\author{
Jerzy WOYKE and Zygmunt JASIÑSKI \\ Bee Division, Agricultural University, Nowoursynowska 166, \\ 02-766 Warszawa, Poland
}

\begin{abstract}
SUMMARY
Honeybee queens were instrumentally inseminated with $8 \mathrm{~mm}^{3}$ of semen. Next they were kept without workers in nursery cages in a colony, or with 0 up to 350 attendant worker bees in small boxes placed in an incubator at $34^{\circ} \mathrm{C}$. The queens were killed and dissected two days after insemination. Queens kept in nursery cages had on the average 2.5 million spermatoza in their spermatheca. An increasing number of attendant workers resulted in a higher number of spermatozoa penetrating queens spermatheca. The highest number of 4.5 million of spermatozoa was found in the spermatheca of queens kept with 250 workers after instrumental insemination. These queens had 1.8 times more spermatozoa in the spermatheca than those kept without workers. It is recommended to keep queens for two days in an incubator after instrumental insemination, with 250 attendant workers.
\end{abstract}

\section{INTRODUCTION}

A naturally well mated queen has about 5.3 million spermatozoa in the spermatheca, while a drone ejaculates 11 million sperms. But after the insemination of a queen with semen of one drone, only 1.4 million sperms enter the spermatheca (WOYKE 1960, 1962). WOYKE (1979) reviewed recent investigations on methods allowing to increase the number of spermatozoa penetrating spermatheca of instrumentally inseminated queens. He found that queens should be attended by workers immediately after instrumental insemination, in order to increase the number of spermatozoa entering the spermatheca.

Till now queens were treated, in different ways immediately after insemination :

a) They were transferred to nursery cages without workers, and returned to nursery colonies or nuclei (LAIDLAW 1954, MACKENSEN 1954, MACKENSEN and Tucker 1970, Vesely 1970, Woyke 1978 and Woyke and JAsiŃski 1978). 
b) They were kept in individual cages together with a few worker bees in an incubator (MACKensen 1955, WoyKe 1960, 1973 and Foti et al. 1975).

c) They were released freely into nuclei or colonies (LAIDLAW 1954, MACKENSEN 1954, Woyke 1963, Vesely 1966, RutTNER 1971).

d) WOYKe (1978 and 1979) also recommended to keep queens after insemination in special boxes with more workers, or to place them on combs in queen excluder isolators which remain in colonies until queens start to lay eggs.

The following question arises now : which is the number of workers necessary to attend queens after instrumental insemination?

\section{MATERIALS AND METHODS}

All virgin queens originated from one Caucasian queen. They emerged and were kept afterwards in nursery cages placed in queenless nursery colonies. A total of 150 virgin queens $7-10$ day old were inseminated, with $8 \mathrm{~mm}^{3}$ of semen each. They were introduced immediately after insemination into small boxes with workers varying in number from 0 to 350 . Wooden boxes $5.5 \mathrm{~cm} \times 12 \mathrm{~cm} \times 12 \mathrm{~cm}$ similar to German Okulirkäfige, had one lifted glass side. They were supplied with a piece of comb fastened directly to the back side of the box, as it is practicized in FoTI cages. The boxes were supplied with weak syrup and bee candy. Inseminated queens were introduced to aslept workers treated with $\mathrm{CO}_{2}$. This procedure assured excellent acceptance of queens. Boxes with queens and workers were kept in an incubator at $34^{\circ} \mathrm{C}$. Some control queens were returned to nursery cages or were released free into queenless colonies. Queens inseminated in one day, were introduced to workers of all number combinations of attendante Queens were killed $48 \mathrm{hr}$ after instrumental insemination and the number of spermatozoa in their spermatheca was counted by the methods already described (WoYKE 1979). Fisher's analysis of variance was applied to the results, and new multiple-range test was used to find statistically significant differences.

\section{RESULTS}

\section{Queens attended by 0 to 160 workers}

Table 1 shows, that the number of spermatozoa in the spermatheca of queens kept after insemination in nursery cages in nursery colony was only 2.473 million. Queens kept without workers in nursery boxes in an incubator had about 650 thousand more spermatozoa, than those kept in cages in a colony. The difference was statistically significant. The increase of the number of spermatozoa penetrating into the spermatheca could be caused here by higher temperature in the incubator than in the nursery cage in a colony, as well as by more place for movement of queens in boxes than in cages.

After the queens were attended by 10,20 or 40 workers, no significant increase was found in the number of spermatozoa in the spermatheca of queens. But a 
TABL. 1. - Number of spermatozoa in spermatheca of queens inseminated instrumentally with $8 \mathrm{~mm}^{3}$ of semen and kept afterwards with 0 to 160 attendant workers in an incubator

(10 queens per treatment group)

\begin{tabular}{|c|c|c|}
\hline \multirow{2}{*}{ Content } & \multicolumn{2}{|c|}{ Thousand spermatozca } \\
\hline & Range & $\underset{\text { error }}{\text { Mean }} \pm$ standard \\
\hline Queens in colony in nursery cages & & \\
\hline Without workers & $1,895-2,765$ & $2,473 \pm 85 \mathrm{a}\left({ }^{*}\right)$ \\
\hline Queens in incubator in nursery boxes & & \\
\hline Without workers $\ldots \ldots \ldots \ldots \ldots \ldots \ldots \ldots$ & $2,410-3,872$ & $3,118 \pm 146 b$ \\
\hline With 10 workers & $2,130-3,505$ & $2,933 \pm 146 b$ \\
\hline With 20 workers & $2,780 \cdot 3,435$ & $3,122 \pm 64 b$ \\
\hline With 40 workers & $2,805-3,485$ & $3,094 \pm 82 b$ \\
\hline With 80 workers $\ldots \ldots$. & $2,750-3,985$ & $3,424 \pm 119 \mathrm{c}$ \\
\hline With 160 workers .... & $4,140-4,505$ & $4,351 \pm 41 \mathrm{~d}$ \\
\hline
\end{tabular}

(*) Different letters indicate statistically significant differences between means $P<0.05$.

statistically significant higher number of spermatozoa was found in the spermatheca of queens which were attended by 80 workers. The highest number, 4.351 million of spermatozoa, was found in the spermatheca of queens kept with 160 workers. These queens had about 1900 million more sperms in the spermatheca, than those kept after insemination in nursery cages in colonies, or about 1300 million more, than those kept in the incubator in boxes with $0-40$ workers, or about 0.900 million more than those attended by 80 workers.

\section{Queens attended by 0 to 350 workers or released free in colonies}

The previous experiment showed, that the increase of the number of workers attending instrumentally inseminated queens increased the number of spermatozoa penetrating the spermatheca. But it did not resolve the question, whether further increase of the number of attendants would still increase the number of spermatozoa in the spermatheca.

Results of a second experiment showed (Table 2), that queens kept after insemination in nursery cages without attendants in nursery colonies, had very similar number of spermatozoa in spermatheca to queens kept in the same conditions in the previous experiment. After queens kept in cages without workers were placed in an incubator, only a very low, not significant increase of the number of spermatozoa was noticed. Queens released in boxes without workers had in the spermatheca about 0.400 million more spermatozoa over those kept in nursery cages in colonies. Unfortunately this difference was not found to be statistically 
TABL. 2. - Number of spermatozoa in spermatheca of queens inseminated instrumentally with 8 mm $^{3}$ of semen and kept afterwards with 0 to 350 attendant workers in an incubator or free in bee colonies ( 10 queens per group)

\begin{tabular}{|c|c|c|}
\hline & \multicolumn{2}{|c|}{ Thousand spermatozca } \\
\hline & Range & $\begin{array}{c}\text { Mean } \pm \text { standard } \\
\text { error }\end{array}$ \\
\hline $\begin{array}{l}\qquad \text { Queens in colony } \\
\text { In nursery cage without workers } \ldots \ldots \ldots \ldots \ldots \ldots \ldots \\
\text { Queens in incubator }\end{array}$ & $2,220-2,910$ & $2,577 \pm 77 \mathrm{a}\left({ }^{*}\right)$ \\
\hline 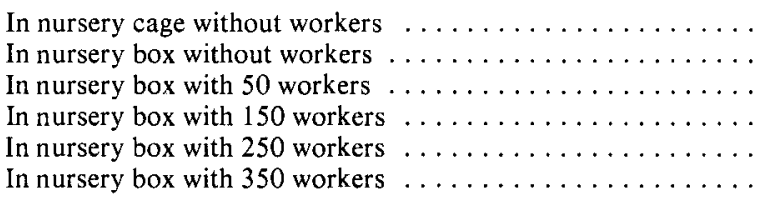 & $\begin{array}{l}2,240-3,215 \\
2,390-3,980 \\
2,510-3,780 \\
3,660-5,920 \\
4,130-6,010 \\
3,725-4,890\end{array}$ & $\begin{array}{l}2,633 \pm 150 \mathrm{a} \\
2,985 \pm 175 \mathrm{ab} \\
3,210 \pm 144 \mathrm{~b} \\
4,432 \pm 250 \mathrm{c} \\
4,514 \pm 191 \mathrm{~cd} \\
4,117 \pm 131 \mathrm{c}\end{array}$ \\
\hline Queens in colony & & \\
\hline Free $\ldots \ldots \ldots \ldots \ldots \ldots \ldots \ldots \ldots \ldots \ldots$ & $4,250-6,710$ & $4,725 \pm 193 d$ \\
\hline
\end{tabular}

(*) Different letters indicate statistically significant differences between means $P<0.05$.

significant. A higher number of queens investigated would probably show here a significant difference, as it was shown in the previous experiment. After 50 workers were added to the box, the number of sperms in the spermatheca increased by 225 thousand only, over that found in queens kept in boxes without workers. But this caused a statistically significant increase of about 600 thousand sperms in the spermatheca over that found in queens kept in nursery cages placed either in a colony or in an incubator. On the other hand, no statistically significant differences were found between the numbers of sperms in spermatheca of queens kept after insemination in an incubator in boxes without attendants or with 50 workers. This shows, that the increase of the number of sperms in spermatheca of queens kept in incubator without workers (Table 1 and Table 2) is mainly caused by the larger room allowing easy movement of the queen in the box and not just by placing the queen in an incubator in a cage.

An increase of the number of attendants up to 150 workers, resulted in a significant increase of 1.222 million sperms in queen's spermatheca over that found in queens attended by 50 workers. A further increase of the number of attendants up to 350 workers did not increase significantly the number of sperms penetrating the queen's spermatheca. The average number of sperms was even lower by 397 thousand in the spermatheca of queens kept with 350 attendants than in that of queens kept with 250 workers. A box with so many bees was crowded and this may be disadvantageous to the queen. The highest average number of sperms, 4.514 million, 
was found in the spermatheca of queens attended by 250 workers. These queens had about 1.900 million more sperms in the spermatheca, than those kept in nursery cages either in a colony or in the incubator, and 1.304 million more, than those attended by 50 workers. Thus queens attended by 250 workers, had 1.8 times more spermatozoa in the spermatheca than those kept without workers.

Queens released free in colonies had an average of 4.725 million sperms in the spermatheca. This number differed significantly from that found in queens kept with 150 or 350 attendant workers. But no statistically significant difference was found between the number of spermatozoa found in the spermatheca of queens released free in the colony and that of queens kept in the incubator with 250 attendant workers.

\title{
CONCLUSION
}

After instrumental insemination it is recommended to keep queens, for two days in an incubator, with 250 attendant workers.

Received for publication in January 1979

\author{
RÉSUMÉ \\ NOMBRE D'OUVRIÈRES ACCOMPAGNATRICES NÉCESSAIRES POUR DES REINES \\ INSÉMINÉES ARTIFICIELLEMENT ET CONSERVÉES A L'ÉTUVE
}

WoyKe (1979) a montré que l'accès des ouvrières aux reines inséminées artificiellement est nécessaire pour qu'augmente le nombre de spermatozoïdes qui pénètrent dans la spermathèque de la reine. Il s'agit de connaitre le nombre d'ouvrières accompagnatrices nécessaires.

\section{Matériel et méthodes}

Cent cinquante reines vierges âgées de 7 à 10 jours ont été inséminées avec $8 \mathrm{~mm}^{3}$ de sperme, puis introduites dans de petites boites de $5,5 \times 12 \times 12 \mathrm{~cm}$ renfermant un nombre variable d'ouvrières, de 0 à 350. Les boîtes possédaient chacune un morceau de rayon, du sirop dilué et du candi. Elles ont été placées dans une étuve à $34{ }^{\circ} \mathrm{C}$. Quelques reines ont été replacées comme groupe témoin dans des cagesnourriceries placées dans des colonies éleveuses ou bien lâchées directement dans diverses colonies. On a tué les reines deux jours après l'insémination et dénombré les spermatozoïdes présents dans la spermathèque.

\section{Résultats}

Dans la première expérience, les reines inséminées artificiellement étaient accompagnées de 0 à 160 ouvrières. Le tableau 1 montre que les reines conservées dans des cages-nourriceries sans ouvrières dans une colonie avaient 2473000 spermatozoïdes dans leur spermathèque, tandis que celles conservées à l'étuve dans de petites boîtes sans ouvrières avaient 650000 spermatozoïdes de plus. Pour les reines accompagnées de 10,20 ou 40 ouvrières on n'a pas noté d'augmentation statistiquement significative. Des spermatozoïdes significativement plus nombreux ont été trouvés dans la spermathèque des reines accompa- 
gnées de 80 ouvrières. Le nombre le plus élevé, 4351000 a été trouvé chez les reines conservées avec 160 ouvrières. Les reines possédaient 1,9 million de plus de spermatozoïdes que celles conservées dans les cages-nourriceries dans une colonie.

Dans la seconde expérience, les reines étaient accompagnées de 0 à 350 ouvrières. Le tableau 2 montre qu'une augmentation jusqu'à 150 du nombre d'ouvrières accompagnatrices a eu pour conséquence un accroissement significatif du nombre de spermatozoïdes qui pénètrent dans la spermathèque de la reine. Un plus grand accroissement du nombre d'accompagnatrices n'a qu'augmenté très peu le nombre de spermatozoïdes. Les reines conservées avec 350 ouvrières avaient même moins de spermatozoïdes que celles conservées avec 250 ouvrières. Le nombre de spermatozoïdes le plus élevé, 4514000 , a été trouvé dans la spermathèque des reines conservées avec 250 accompagnatrices et ne différait statistiquement pas du nombre trouvé dans la spermathèque des reines lâchées directement dans la colonie. Il est par conséquent recommandé de conserver les reines, après insémination artificielle, à l'étuve avec 250 ouvrières accompagnatrices durant deux jours.

\title{
ZUSAMMENFASSUNG
}

\author{
DIE ERFORDERLICHE ANZAHL VON ARBEITSBIENEN ZUR PFLEGE VON \\ INSTRUMENTELL BESAMTEN KÖNIGINNEN BEI HALTUNG IM BRUTSCHRANK
}

Wie WоYKe 1979 zeigen konnte, ist die Anwesenheit von Pflegebienen um eine instrumentell besamte Königin erforderlich, um eine Vermehrung der Anzahl der in die Spermatheka gelangenden Spermien zu erreichen. Es stellt sich die Frage, wie gross die Zahl der Arbeiterinnen für eine gute Pflege der Königin nach der instrumentellen Besamung sein muss.

\section{Material und Methoden}

150 unbegattete Königinnen wurden im Alter von 7-10 Tagen mit $8 \mu 1$ Samen inseminiert. Anschliessend wurden sie zusammen mit einer wechselnden Zahl von Arbeiterinnen (0-350) in Versuchskäfigen $(5,5 \times 12,0 \times 12,0 \mathrm{~cm})$ untergebracht. Die Käfige waren mit einem Wabenstück, dünnem Sirup und Zuckerteig versehen. Sie wurden in einem Brutschrank bei einer Temperatur von $34^{\circ} \mathrm{C}$ gehalten. Als Kontrolle dienten Königinnen, die in weisellosen Völkern gekäfigt oder die in verschiedenen Völkern frei zugesetzt waren. Zwei Tage nach der Besamung wurden die Königinnen getötet, um die Zahl der Spermatozoen in der Spermatheka zu zählen.

\section{Resultate}

Im ersten Experiment wurden der Königin 0-160 Pflegebienen zugegeben. Wie Tab. 1 zeigt, hatten Königinnen, die in einem Käfig ohne Begleitbienen in einem Volk gehalten worden waren, 2,473 Millionen Spermatozoen in der Spermatheka; wurden die Königinnen jedoch im Brutschrank gehalten, ebenfalls in einem Käfig ohne Bienen, so wurden um 650.000 mehr Spermatozoen gefunden. Wurden 10, 20 oder 40 Begleitbienen zugegeben, so war keine signifikante Steigerung der Spermienzahl festzustellen. Deutlich mehr Spermatozoen wurden hingegen nach Zugabe von 80 Arbeiterinnen gefunden. Die grösste Zahl (4,351 Millionen) Spermatozoen wurde bei Königinnen gefunden, die zusammen mit 160 Arbeiterinnen gehalten worden waren. Diese Königinnen hatten um 1,9 Mill. mehr Spermien als Königinnen, die in Pflegevölkern gekäfigt gewesen waren.

In einem zweiten Experiment schwankte die Zahl der zugegebenen Pflegebienen zwischen 0-350. Tab. 2 zeigt, dass bei einer Steigerung der Bienenzahl bis zu 150 Arbeiterinnen gleichzeitig eine signifikante Erhöhung der Spermatozoenzahl in der Spermatheka eintritt. Durch eine weitere Steigerung der Bienenzahl wurde die Spermienzahl in der Spermatheka nur in geringem Masse erhöht. Königinnen, die von 350 Bienen gepflegt worden waren, wiesen sogar weniger Spermatozoen auf als solche mit 250 Arbeiterinnen. Die höchste Zahl von 4,514 Millionen Spermatozoen wurde bei Königinnen gefunden, die 
mit 250 Pflegebienen gehalten worden waren; diese Zahl weicht statistisch nicht von derjenigen ab, die bei Königinnen nach freiem Zusetzen in einem Volk gefunden worden war.

Es wird deshalb empfohlen, Königinnen nach der instrumentellen Besamung für zwei Tage zusammen mit 250 Pflegebienen in einem Brutschrank zu halten.

\section{REFERENCES}

Foti N., Grosu E. and Dragan M., 1975. - Comparative research on migration of spermatozoa in caged queens, both naturally mated and artificially inseminated. 25 Intern. Apicult. Congr. Grenoble : 270274.

Laidlaw H. H. Jr., 1954. - Beekeeping management for bee breeder. Am. Bee J. 94 (3) : 92-95.

MACKENSEN O., 1954. - Some improvements in method and syringe design in artificial insemination of queen bees. J. econ. Ent. 47 (5) : 765-768.

MACKENSEN O., 1955. - Experiments in the technique of artificial insemination of queen bees. J. econ. Ent., 48 (4) : 418-421.

MACKENSEN O. and TUCKer K. W., 1970. - Instrumental insemination of queen bees. Agric. Handbook. No. 350,28 pr., USDA. Washington.

RUTTNER F., 1971. - Personnal observations of the author.

VESELY V., 1966. - Description of, and handling with, the insemination equipment used at the Course on Artificial Insemination of the queen bees at Dol : 35-67+5 p. fig. Dol. CSSR.

VESELY V., 1970. - Retention of semen in the lateral oviducts of artificially inseminated honey-bee queens (Apis mellifera L.) Acta entom. bohemosl. 67 (2) : 82-92.

Woyke J., 1960. - Natural and artificial insemination of queen bees. Pszczeln. Zesz. Nauk. 4 (3-4) : 183275. Also Bee World 1962. 43, $1: 21-25$.

WOYKE J., 1963. - The behaviour of queens inseminated artificially in different manner. 19 Intern. Beekeeping Congress : 702-703 Prague.

WOYKE J., 1973. - Artificial insemination of Apis cerana indica queens. J. apic. Res. 12 (3) : 151-158.

WOYKE J., 1978. - Biology of reproduction and genetics of the honeybee. Final Techn. Rep. for USDA, Bee Cult. Div., Agr. Univ. Warsaw 381 pp.

WoyKE J., 1979. - Effect of the access of worker honeybees to the queen on the result of instrumental insemination. $J$, apic. Res. 18 (in press).

WOYKE J. and JASIŃSKI Z., 1978. - Influence of age of drones on the results of instrumental insemination of honeybee queens. Apidologie, 9 (3) : 203-212. 